\title{
A Study on the Problems and Prospects of Women Entrepreneurs with Special Reference to Guwahati City
}

\author{
Priyanka Sharma \\ PhD Research Scholar, \\ Department of Economics, Gauhati University, Assam, India.
}

\begin{abstract}
Women entrepreneur is a person who accepts challenging role to meet her personal needs and become economically independent. Entrepreneurship is an economic activity that involves designing, launching and running a new business enterprise in order to earn the profit by fully and efficiently utilizing the resources.The present paper tries to highlight the problems and prospects of women entrepreneurs with special reference to Guwahati city and makes analysis on the basis of the following criteria viz,age of the respondents, marital status of the respondents, educational qualification,years of experience,type of family,caste of the respondents,reason to start the business,motivation to start the business, marketing and financial problems faced by the women entrepreneurs, family-work conflict,production constraint faced by the women entrepreneurs, steps to be undertaken for development of women entrepreneurs etc and for analysis the researcher has conducted its study on the basis of primary data where the information were collected through well framed questionnaire meant for women entrepreneurs and secondary sources like journals,books,articles, websites etc.The paper also present certain findings of the study and also provide certain suggestions for improving the status of women entrepreneurs in the city.
\end{abstract}

Keywords: Entrepreneurship, Marital Status, Caste, Educational Qualification, Family-Work Conflict, Production Constraint.

\section{INTRODUCTION}

Women entrepreneur is a person who accepts challenging role to meet her personal needs and become economically independent. Entrepreneurship is an economic activity that involves designing,launching and running a new business enterprise in order to earn the profit by fully and efficiently utilizing the resources.According to Joseph Schumpeter an entrepreneur is a person who is willing and able to covert a new idea or innovation into successful invention into a successful innovation.Economist Schumpeter saw the role of entrepreneur as creative destructions-launching innovations that simultaneously destroy old industries while ushering in new industries and approaches.Entrepreneurship plays a significant role in the growth and development of a nation and it contributes towards country's GDP.However in the pre-independence time it was seen that women were bound to stay at home within the four walls keeping themselves busy in household chores. There was a strict restriction on their mobility.But in the post independence period it was observed that the gender biasness were significantly coming down and women started contributing to family's income and gradually there has been an increasing participation of women in the development of entrepreneurship. Women are infact the best entrepreneurs as they can run their houses so effectively. They have the potentialities to go further but what is needed is their exposure to the external world and with the passage of time women entrepreneurs are increasing. 


\section{PROBLEMS OF ENTREPRENEURS}

1. The most crucial problem faced is the mindset of the people. Whenever a woman wants to start a business of her own,the first question which arises is the source of capital,reliability on the long term plans women has in business.

2.The greatest hindrance to women entrepreneurs is that they are women.A kind of patriarchal male dominant social order is the building block to them in their way towards business success.Male members consider it very risky to finance the ventures run by the women.

3.The financial institutions are skeptical about the entrepreneurial abilities of women.The bank consider risky to grant loans to women.

4.Women family obligations also obstruct from becoming successful entrepreneurs in both developing and developed nations. They have primary responsibility for children,home and older,dependent family members.

5. Low level risk taking attitude is another factor which affects women decision to get into business.Low level education provides low self confidence and self reliance to the women folk to engage in business which is a continuous risk taking profession.

6.High production cost of some business operations adversely affects the development of women entrepreneurs.The installation of new machines during expansion of the productive capacity dissuades the women entrepreneur from venturing into new areas.

7.Women Entrepreneurs do not have organizational set up to pump in a lot of money for canvassing and advertisement and thus they have to face a stiff competition for marketing their products with the organized sector as well as their male counterparts.
8. Women have to face difficulty in their mobility as compared to their male counterparts.

\section{PROSPECTS OF WOMEN ENTREPRENEUR}

Though the women entrepreneurs are facing many problems, the prospect of the women entrepreneurs cannot be undermined.The Government of India and the banks and the financial institutions play a significant role in the development of women entrepreneur.The government of India from time to time is launching various schemes for the development of women entrepreneurs. Theprospect for the development of women entrepreneurs is only possible when society,financial institutions collectively take initiatives.Government of India has entrusted the responsibility of women entrepreneur i.e. small and medium enterprise to the ministry of MSME.Ministry of MSME has launched many schemes for the development of entrepreneurship.

\section{RATIONALE OF THE STUDY}

Entrepreneurship amongst women is relatively a recent phenomenon which is gradually changing with the growing sensitivity of roles,responsibilities and economic status of women in the society in general and family in particular.For women entrepreneurs,starting and operating a business involves considerable risk and difficulties,but the efforts of Government of India through various welfare organizations,non government agencies,Ministry of Commerce and other agencies have started looking after them and helping them in their efforts. This study discuss about the problems faced by women entrepreneurs and the opportunities that is in favour of them so that they can run their business successfully thereby contributing towards the society.

\section{OBJECTIVES}

1.To identify the prevailing entrepreneurship initiatives by women in the city of Guwahati

2.To identify the prospects of women entrepreneurs in Guwahati. 
3.To study the challenges and opportunities faced by women entrepreneurs.

4.To ascertain the constraints faced by the women in running their business.

\section{REVIEW OF LITERATURE}

Pooja Nayyar and et al(2007) conducted a study on hundred women entrepreneurs selected through random and snowball technique from four zones of Himachal Pradesh .Nursing homes,boutiques, handloom units, beauty parlours,carpet making units and general stores were the enterprises selected for study. The objectives of the endeavor were to ascertain the financial,marketing and production constraints faced by the women in their enterprise, assessment of their health status, work place facilities and to develop guides for becoming successful entrepreneurs.Support mechanism such as institutional credit needs to be strengthened to keep entrepreneurs about loaning schemes/credit facilities for further expansion.

Subhash Limbu and NabasmitaBordoloi(2015)The study was undertaken with an objective to study the problems and prospects of rural Assam's women entrepreneurs.Interview method was used to collect data from women entrepreneurs.Information on prospects and problems of entrepreneurship were gathered and analyzed.The results of the study indicate that the society have to change their stereotyped mindset over women entrepreneurs. The women in the rural areas are subject to lots of restrictions in Assam.The opportunity as provided for the women entrepreneurs by the institutions is not adequate.To increase the numbers of rural women entrepreneurs, their requires a coordinated action from different stockholders of the society. In this study it was found that there was lack of support from the state government.

\section{METHODOLOGY}

The present study is based on descriptive research.The data is collected from primary sources as well as secondary source. The primary data were collected from the 40 respondents through a well framed questionnaire meant for women entrepreneurs in Guwahati.The researcher collected secondary data from sources like journals, articles, books, websites etc.The researchers have used convenience sampling technique.

\section{DATA ANALYSIS AND INTERPRETATION TABLE NO: 1}

\section{AGE OF THE RESPONDENTS}

\begin{tabular}{|l|l|l|}
\hline $\begin{array}{l}\text { AGE(in } \\
\text { years) }\end{array}$ & $\begin{array}{l}\text { No of } \\
\text { respondents }\end{array}$ & $\begin{array}{l}\text { Percentage of } \\
\text { respondents }\end{array}$ \\
\hline $21-30$ & 18 & 45 \\
\hline $31-40$ & 15 & 37.5 \\
\hline $41-50$ & 5 & 12.5 \\
\hline $\begin{array}{l}\text { Above } 51 \\
\text { years }\end{array}$ & 2 & 5 \\
\hline TOTAL & 40 & 100 \\
\hline
\end{tabular}

Source: Field survey

\section{INTERPRETATION}

The above table reveals that 45 percent of the respondents belong to the age group of 21-30 years,37.5 percent belongs to the age group of 3140 years. 12.5 percent belongs to the age group of 41-50 years. 5 percent belong to the age group of above

years.

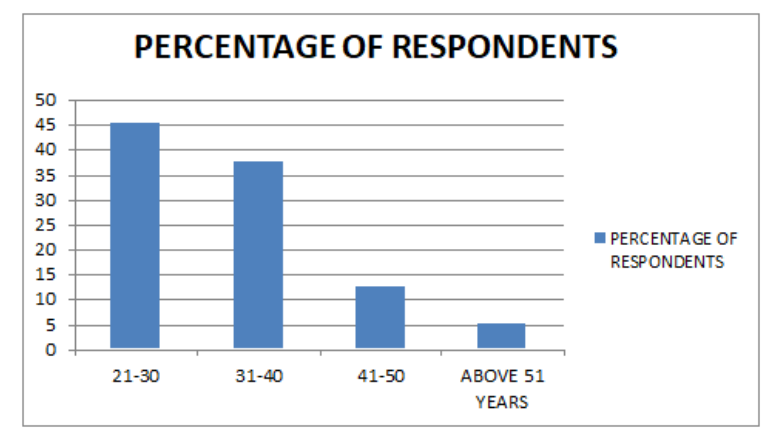


TABLE NO: 2

MARITAL STATUS OF THE RESPONDENT

\begin{tabular}{|l|lr|l|}
\hline MARITA & $\begin{array}{l}\text { NO OF } \\
\text { L } \\
\text { STATUS }\end{array}$ & $\begin{array}{l}\text { RESPONDEN } \\
\text { TS }\end{array}$ & $\begin{array}{l}\text { E RESPONDEN } \\
\text { TS }\end{array}$ \\
\hline SINGLE & 10 & 25 \\
\hline $\begin{array}{l}\text { MARRIE } \\
\text { D }\end{array}$ & 29 & 72.5 \\
\hline WIDOW & 1 & 2.5 \\
\hline TOTAL & 40 & 100 \\
\hline
\end{tabular}

Source:Field Survey

\section{INTERPRETATION}

The above table reveals that 25 percent of the women are single and 72.5 percent women are married and 2.5 percent women are widow.

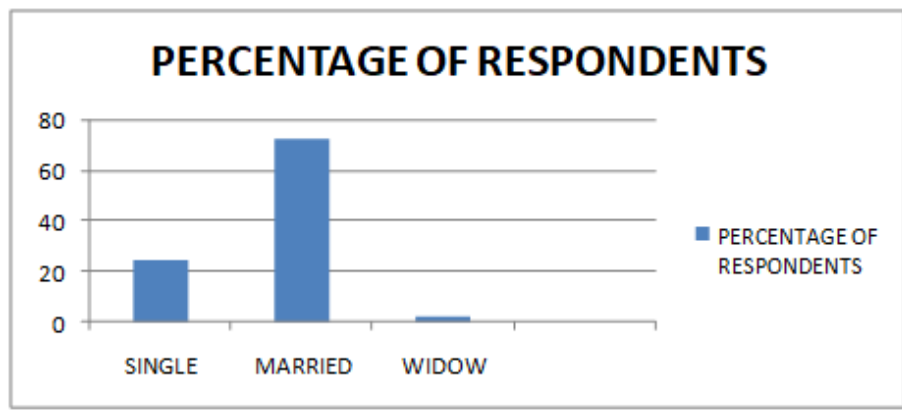

TABLE NO:3

EDUCATION QUALIFICATION

\begin{tabular}{|c|c|c|}
\hline QUALIFICATION & $\begin{array}{c}\text { NO.OF } \\
\text { RESPONDENTS }\end{array}$ & $\begin{array}{c}\text { PERCENTAGE } \\
\text { OF } \\
\text { RESPONDENTS }\end{array}$ \\
\hline MATRICULATION & $\mathbf{1 0}$ & $\mathbf{2 5}$ \\
\hline H.S. & $\mathbf{5}$ & $\mathbf{1 2 . 5}$ \\
\hline UG DEGREE & $\mathbf{2 3}$ & $\mathbf{5 7 . 5}$ \\
\hline PG DEGREE & $\mathbf{2}$ & $\mathbf{5}$ \\
\hline TOTAL & $\mathbf{4 0}$ & $\mathbf{1 0 0}$ \\
\hline
\end{tabular}

Source:Field Survey

The above table reveals that 25 percent of respondents did matriculation,12.5 percent of respondents did their higher secondary,57.5 percent of respondents are graduates, 5 percent of respondents are post graduate.

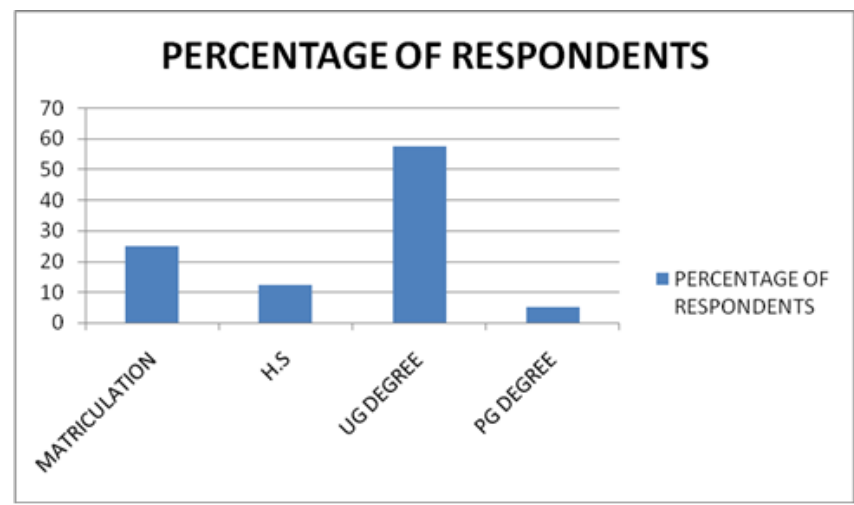

TABLE NO:4

YEAR OF EXPERIENCE OF THE RESPONDENTS

\begin{tabular}{|l|l|l|}
\hline YEARS & $\begin{array}{l}\text { NO OF } \\
\text { RESPONDENTS }\end{array}$ & $\begin{array}{l}\text { PERCENTAGE } \\
\text { OF } \\
\text { RESPONDENTS }\end{array}$ \\
\hline $\begin{array}{l}\text { UPTO 1 } \\
\text { YEAR }\end{array}$ & 5 & 12.5 \\
\hline $\begin{array}{l}\text { 2-5 } \\
\text { YEARS }\end{array}$ & 21 & 52.5 \\
\hline $\begin{array}{l}\text { 6-8 } \\
\text { YEARS }\end{array}$ & 13 & 32.5 \\
\hline $\begin{array}{l}\text { 9-12 } \\
\text { YEARS }\end{array}$ & 1 & 2.5 \\
\hline $\begin{array}{l}\text { ABOVE } \\
\text { 12 } \\
\text { YEARS }\end{array}$ & 0 & 0 \\
\hline TOTAL & 40 & 100 \\
\hline
\end{tabular}

Source:Field Survey

The above table reveals that 52.5 percent of the respondents have experience of 2-5 years,32.5 percent of respondents have experience of 6-8 years, 2.5 percent of respondents have experience of 9-12 years and 12.5 percent of the respondents have experience of 1 year. 


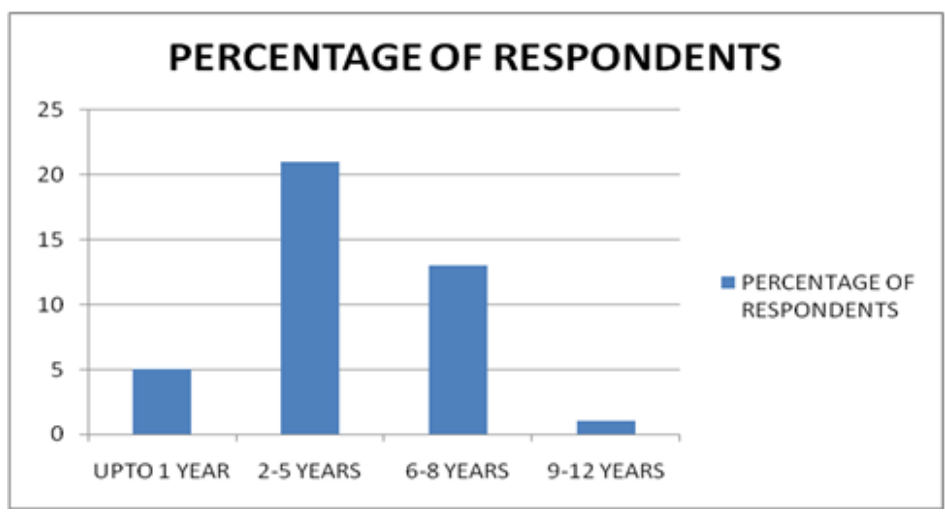

TABLE NO:5

TYPE OF FAMILY

\begin{tabular}{|l|l|l|}
\hline $\begin{array}{l}\text { FAMILY } \\
\text { TYPE }\end{array}$ & $\begin{array}{l}\text { NO.OF } \\
\text { RESPONDENTS }\end{array}$ & $\begin{array}{l}\text { PERCENTAGE } \\
\text { OF } \\
\text { RESPONDENTS }\end{array}$ \\
\hline NUCLEAR & 34 & 85 \\
\hline $\begin{array}{l}\text { JOINT } \\
\text { FAMILY }\end{array}$ & 6 & 15 \\
\hline TOTAL & 40 & 100 \\
\hline
\end{tabular}

Source:Field Survey

The above table reveals that 85 percent of women respondents have nuclear family and 15 percent of women respondents have joint family

\section{PERCENTAGE OF RESPONDENTS}

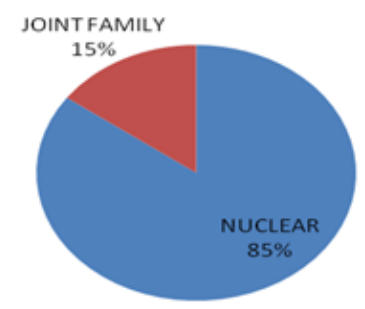

TABLE NO:6

CASTE OF THE RESPONDENTS

\begin{tabular}{|l|l|l|}
\hline CASTE & $\begin{array}{l}\text { NO.OF } \\
\text { RESPONDENTS }\end{array}$ & $\begin{array}{l}\text { PERCENTAGE } \\
\text { OF } \\
\text { RESPONDENTS }\end{array}$ \\
\hline GENERAL & 27 & 67.5 \\
\hline OBC & 9 & 22.5 \\
\hline SC/ST & 3 & 7.5 \\
\hline OTHER & 1 & $\mathbf{2 . 5}$ \\
\hline TOTAL & $\mathbf{4 0}$ & $\mathbf{1 0 0}$ \\
\hline
\end{tabular}

Source:Field Survey
The above table reveals indicate 67.5 percent of respondents belong to General Category while 22.5 percent,7.5 percent, 2.5 percent belongs to $\mathrm{SC} / \mathrm{ST}$ and other category respectively.

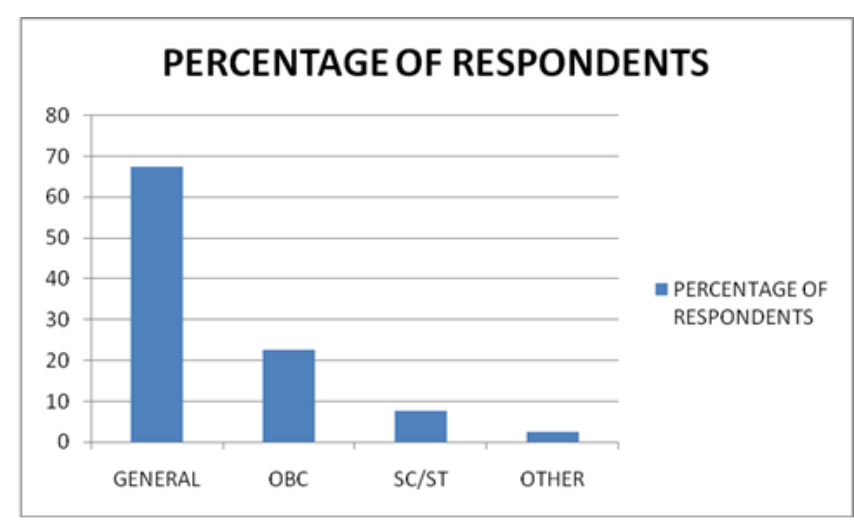

TABLE NO:7

REASON TO START THE BUSINESS

\begin{tabular}{|l|l|l|}
\hline REASONS & $\begin{array}{l}\text { NO. OF } \\
\text { RESPONDENTS }\end{array}$ & $\begin{array}{l}\text { Percentage } \\
\text { of } \\
\text { respondents }\end{array}$ \\
\hline BREAD WINNER & 4 & 10 \\
\hline $\begin{array}{l}\text { SUDDEN FALL IN } \\
\text { INCOME }\end{array}$ & 5 & 12.5 \\
\hline $\begin{array}{l}\text { INADEQUATE } \\
\text { INCOME OF THE } \\
\text { FAMILY }\end{array}$ & 9 & 22.5 \\
\hline $\begin{array}{l}\text { TO IMPROVE } \\
\text { THE STANDARD } \\
\text { OF LIVING }\end{array}$ & 19 & 47.5 \\
\hline $\begin{array}{l}\text { ALL OF THE } \\
\text { ABOVE }\end{array}$ & 3 & 7.5 \\
\hline TOTAL & 40 & 100 \\
\hline
\end{tabular}

Source:Field Survey

The above table reveals that 47.5 percent of the respondents started their business to improve their standard of living whereas 10,12.5,22.5,7.5 percent of respondents started their business for different reasons. 


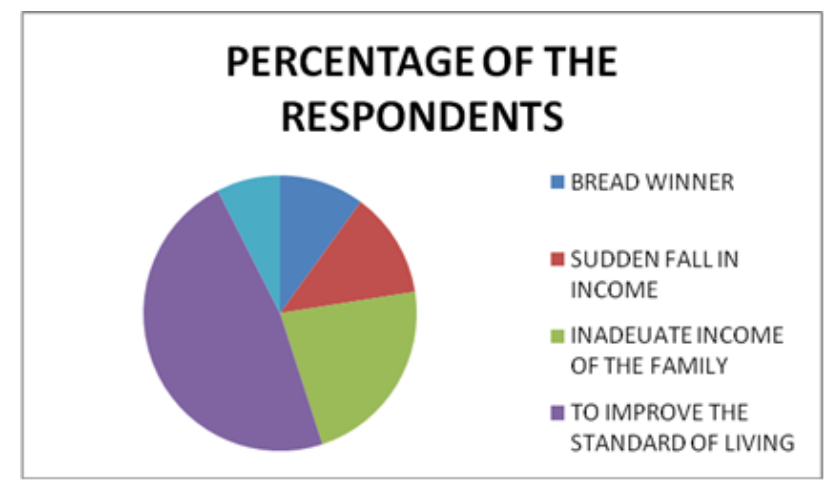

TABLE NO:8

MOTIVATION TO START THE BUSINESS

\begin{tabular}{|l|l|l|}
\hline MOTIVATION & $\begin{array}{l}\text { NO. OF } \\
\text { RESPONDEN } \\
\text { TS }\end{array}$ & $\begin{array}{l}\text { PERCENTAG } \\
\text { RESPONDEN } \\
\text { TS }\end{array}$ \\
\hline $\begin{array}{l}\text { DESIRE TO } \\
\text { UTILIZE } \\
\text { TALENT }\end{array}$ & 6 & 15.4 \\
\hline $\begin{array}{l}\text { TO UTILIZE } \\
\text { TIME AND } \\
\text { EDUCATION }\end{array}$ & 6 & 15.4 \\
\hline $\begin{array}{l}\text { TO GET } \\
\text { ECONOMIC } \\
\text { INDEPENDEN } \\
\text { CE }\end{array}$ & & 26.9 \\
\hline $\begin{array}{l}\text { TO GAIN } \\
\text { SOCIAL } \\
\text { RECOGNITIO } \\
\text { N AND } \\
\text { STATUS }\end{array}$ & & 11.5 \\
\hline $\begin{array}{l}\text { ALL OF THE } \\
\text { ABOVE }\end{array}$ & 12 & \\
\hline TOTAL & 40 & 100 \\
\hline
\end{tabular}

Source:Field survey

The above table reveals that 30.8 percent of women entrepreneurs are motivated to start their business to get economic independence,to utilize time and education,to utilize talent and to get recognition

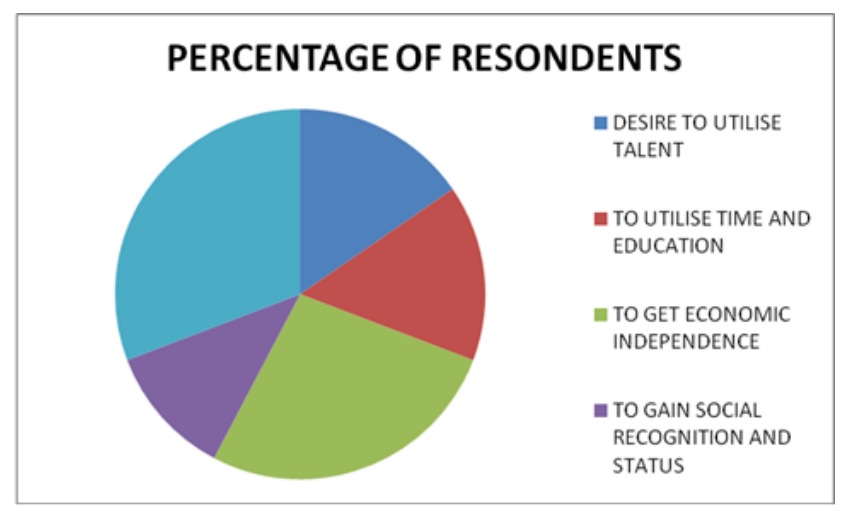

TABLE NO: 9

MARKETING PROBLEM FACED BY WOMEN ENTREPRENEUR

\begin{tabular}{|l|l|l|}
\hline & $\begin{array}{l}\text { NO. OF } \\
\text { RESPONDENT } \\
\text { S }\end{array}$ & $\begin{array}{l}\text { PERCENTAGE } \\
\text { OF } \\
\text { RESPONDENT } \\
\text { S }\end{array}$ \\
\hline YES & 26 & $65.4 \%$ \\
\hline NO & 5 & $11.5 \%$ \\
\hline $\begin{array}{l}\text { SOMETIME } \\
\text { S }\end{array}$ & 9 & $23.1 \%$ \\
\hline TOTAL & 40 & 100 \\
\hline
\end{tabular}

Source:Field Survey

The above table reveals that 65.4 percent of respondents faced marketing constraints in running their business, 11.5 percent do not face marketing problems,23.1 percent of respondents sometimes face marketing problems.

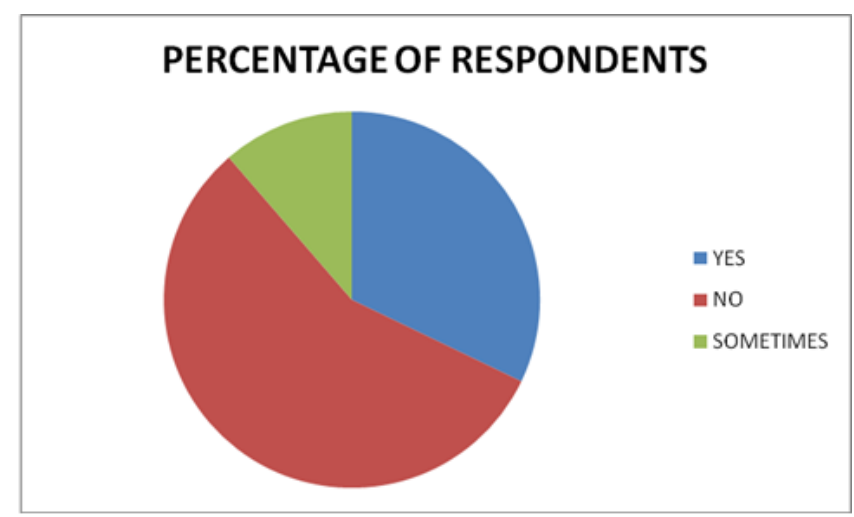


TABLE NO: 10

FINANCIAL PROBLEMS FACED BY THE BUSINESS

\begin{tabular}{|c|c|c|}
\hline $\begin{array}{l}\text { FINANCIAL } \\
\text { PROBLEMS }\end{array}$ & $\begin{array}{l}\text { NO.OF } \\
\text { RESPONDEN } \\
\text { TS }\end{array}$ & $\begin{array}{l}\text { PERCENTAG } \\
\text { E } \\
\text { RESPONDEN } \\
\text { TS }\end{array}$ \\
\hline $\begin{array}{l}\text { NON } \\
\text { AVAILABILIT } \\
\text { Y OF LONG } \\
\text { TERM } \\
\text { FINANCE }\end{array}$ & 13 & 32.5 \\
\hline $\begin{array}{l}\text { LACK OF } \\
\text { AWARENESS } \\
\text { ABOUT } \\
\text { GOVERNMEN } \\
\text { T FINANCIAL } \\
\text { AID SCHEME } \\
\end{array}$ & 8 & 20 \\
\hline $\begin{array}{l}\text { LONG } \\
\text { PROCEDURE } \\
\text { TO AVAIL } \\
\text { FINANCIAL } \\
\text { HELP } \\
\end{array}$ & 8 & 20 \\
\hline $\begin{array}{l}\text { LACK OF } \\
\text { GOVERNMEN } \\
\text { T SUPPORT }\end{array}$ & 5 & 12.5 \\
\hline $\begin{array}{l}\text { ALL OF THE } \\
\text { ABOVE }\end{array}$ & 6 & 15 \\
\hline TOTAL & 40 & 100 \\
\hline
\end{tabular}

Source:Field Survey

The above table reveals that 32.5 percent of respondents faced non-availability of long term finance, 20 percent of respondents faced non availability of long term finance, 20 percent of respondents faced lack of awareness about government financial aid scheme and long term procedure to avail financial help.While 12.5 percent felt lack of government support.

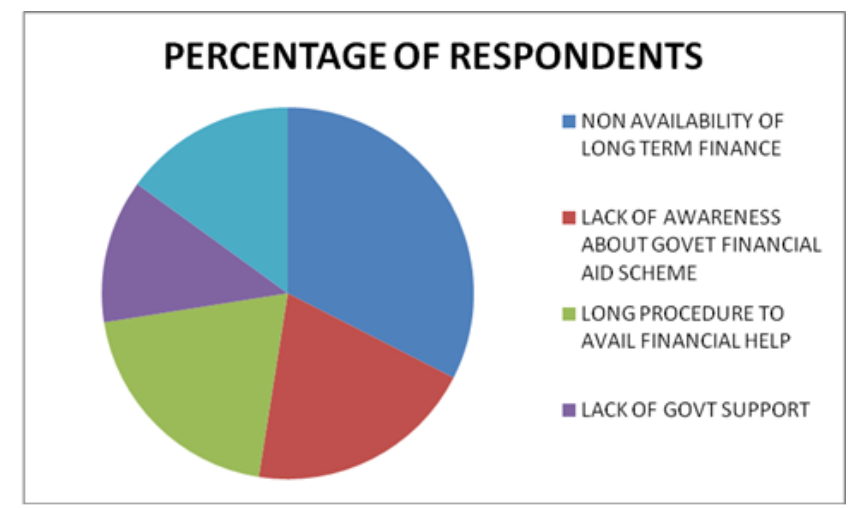

TABLE NO: 11

FAMILY WORK CONFLICT FACED BY WOMEN ENTREPRENEURS

\begin{tabular}{|l|l|l|}
\hline & $\begin{array}{l}\text { NO. OF } \\
\text { RESPONDENT } \\
\text { S }\end{array}$ & $\begin{array}{l}\text { PERCENTAG } \\
\text { E RESPONDENT } \\
\text { S }\end{array}$ \\
\hline YES & 25 & 62.5 \\
\hline NO & 12 & 30.8 \\
\hline $\begin{array}{l}\text { SOMETIME } \\
\text { S }\end{array}$ & 3 & 7.7 \\
\hline TOTAL & 40 & 100 \\
\hline
\end{tabular}

Source:Field Survey

The above table reveals that $62.5 \%$ of respondents faced family work conflict ,30.8 percent of respondents didn't faced any kind of these problems while 7.7 percent of respondents sometimes face work family conflict.

\section{PERCENTAGE OF RESPONDENTS}

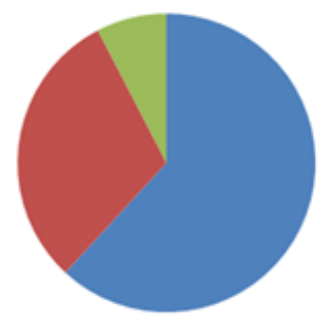

- YES

- NO

= SOMETIMES 
TABLE NO: 12

PRODUCTION CONSTRAINTS FACED BY WOMEN ENTREPRENEURS

\begin{tabular}{|l|l|}
\hline PRODUCTION CONSTRAINTS & NO \\
\hline $\begin{array}{l}\text { NON-AVAILABILITY OF RAW MATERIAL } \\
\text { AND EQUIPMENT }\end{array}$ & 5 \\
\hline LACK OF TRAINING FACILITY & 19 \\
\hline LACK OF REPAIRING FACILITY & 3 \\
\hline NON AVAILABILITY OF LABOUR FORCE & 9 \\
\hline ALL OF THE ABOVE & 4 \\
\hline TOTAL & 40 \\
\hline
\end{tabular}

Source:Field Survey

The above table reveals that $47.5 \%$ of respondents faced production constraints due to lack of training facilities,22.5 percent of respondents faced production constraints due to non availability of labour force.

\section{Source:Field Survey}

The above table reveals that 62.5 percent of

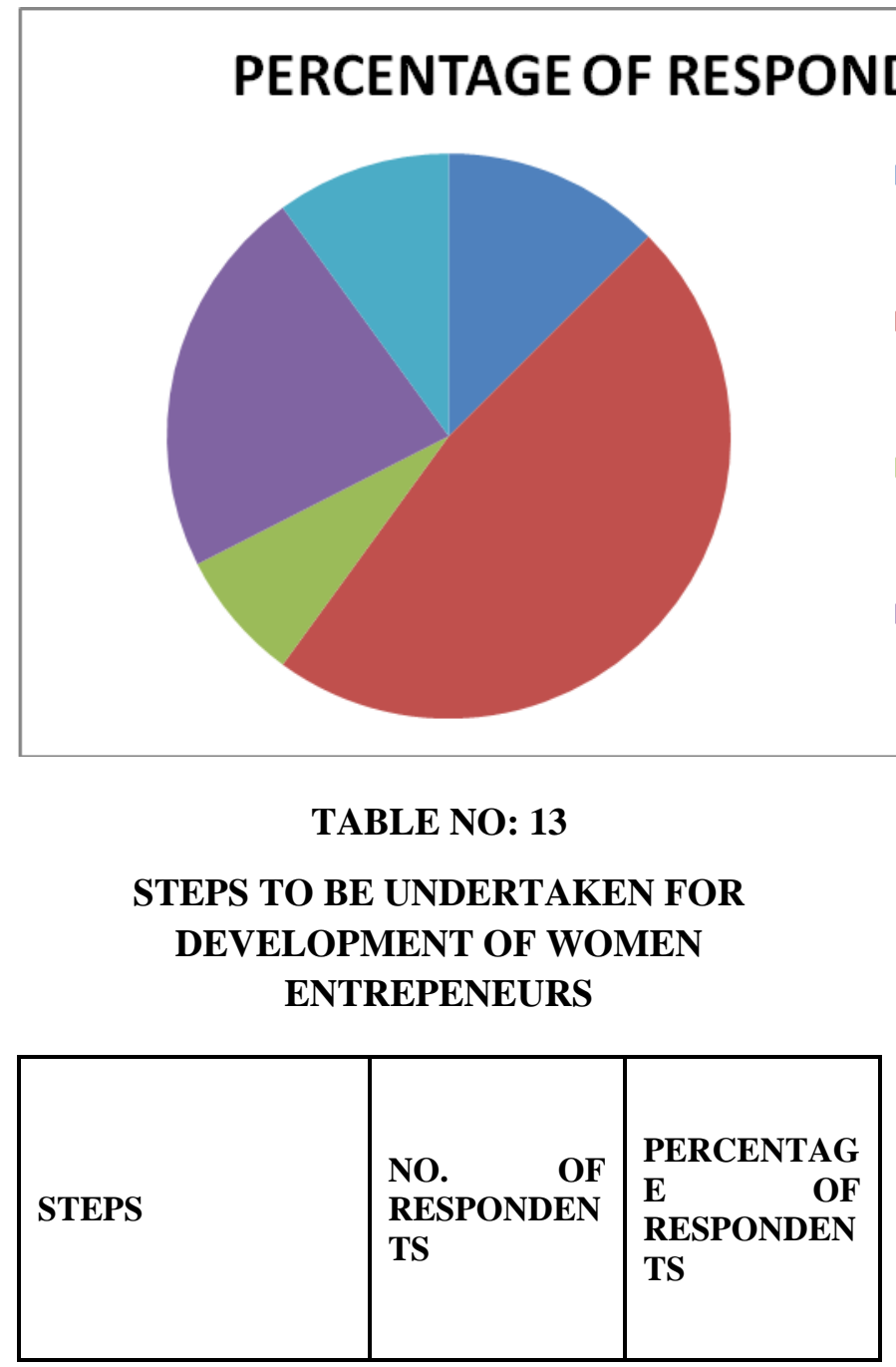

respondents wants better promotion of women ehtepreneurs, better educational and skill deyelopment institutes and wants positive RAwawAremess angong women about the benefits of

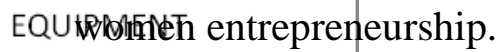

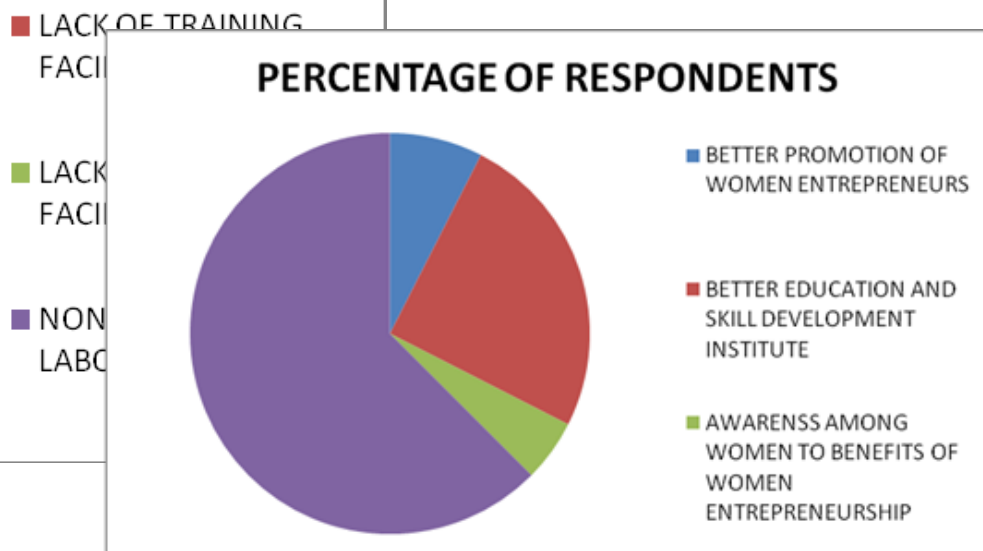

\section{FINDINGS OF THE STUDY}

- Majority (82.5 percent)of women entrepreneurs belong to the age group 21-40

- Majority (72.5 percent) of women entrepreneurs are married

- Majority of women (57.5 percent)women entrepreneurs are graduates. 
- Majority of women (52.5 percent) women entrepreneurs have experience of 6-8 years.

- Majority of women (85 percent) entrepreneurs have nuclear family.

- Majority of women (67.5 percent) entrepreneurs belong to general category.

- Majority of women (47.5 percent) started their business to improve the standard of living.

- Women Entrepreneurs(15.4 percent) were motivated to utilize their talent, 15.4 percent women entrepreneurs were motivated to start their business to utilize time and education.Women entrepreneurs(26.9 percent) wanted to get economic independence,11.5 women entrepreneurs wanted to gain social recognition and social status by running their business where 10 percent of women choose all of the above option.

- Majority of women entrepreneurs(32.5 percent faced the financial problem of non availability of long term finance.

- Majority of women entrepreneurs(62.5 percent)faced work family conflict in running their business.

- Majority of women entrepreneurs(47.5 percent) faced production problem due to lack of training facility.

- Women Entrepreneurs(7.5 percent) choose better promotion of women entrepreneurs for the steps to be undertaken for development of women entrepreneurs, 25 percent of

entrepreneurs choose better education and skill development institute for the steps to be undertaken for development of women entrepreneurs whereas 5 percent of entrepreneurs choose better awareness among the women for the benefits of women entrepreneurship for the step to be taken for the development of women entrepreneurs while 62.5 percent of women entrepreneurs choose all the above option in the questionnaire.

\section{SUGGESTIONS}

1. There are many problems in relation to guidance as stated by the women entrepreneurs. The concentration of marketing and production problems were found to be serious nature which may also be rectified by using the finding associated to this study.

2. Women entrepreneurs have also communicated several financial problems in relation to non availability of long term financial aid.Attention of the government as well as the voluntary organizations should be drawn in rectifying the problems by providing assistance and introducing new facilities for enhancement of the status of the enterprise.

3. Proper training facilities should be established to nurture the talents and skills of women entrepreneurs.

4. Campaigns in the city should be organized to spread awareness about the benefits of being women entrepreneur.

5. Women entrepreneurs must be provided freedom with respect to their mobility. They have to leave the family and make business tours or travel alone or with others,stay in a new place and no restrictions must be provided in this regard.

\section{CONCLUSION}

This research is a rewarding exercise to the researcher to gain more knowledge on the role of women entrepreneur.It concluded that most of the women entrepreneurs are facing the constraints in running their business. The constraints include financial,production,marketing and family work.For effective sustainable development and technology transfer for women entrepreneurs proper training based on scientific inputs,suitable product ideas,product identification,market survey,project formulation and necessary approvals from the government at the right time with less legal formalities,soft recovery rules are of utmost 
importance.Finance should be made available to women entrepreneurs at a reduced rate of interest.The women entrepreneurs should be strongly supported by their family. The family should understand them and give way for continuing their efforts for becoming and being a women entrepreneur.The women should be treated as a supplementary income providers to their family.

\section{REFERENCES}

[1]. Kishore N. Choudhary and Dr. Arvind P.Rayalwar(2011) "Opportunities and Challenges for Rural Women Entrepreneurship in India" Journal Volume 01 Issue III February 2011.Page no-92 to 105

[2]. LavanyaKumariR;Venkatesh J. "A case study on women entrepreneurship and the opportunity to promote India's Development" Journal Volume -02 Issue III April 2015 Page no- 73 to 79

[3]. Subhash Limbu and NabasmitaBordoloi“"Women

Entrepreneurship:Problems and Prospects in Rural Assam"Volume-1 Year2015,JanuaryISSN-2395-4335Page No-117125

[4]. Dr.SwapnaDutta,L.T.K College"Problems of Women Entrepreneurship in Assam:A Case study in Lakhimpur District"Volume-1,Issue1,July,2016Page No 22-29

[5]. "A dedicated platform for women entrepreneurs of Assam"G PLUS,Digital DeskJanuary,25,2018Source-GPLUS.com

[6]. Mala Mahanta"Importance and challenges of women entrepreneurship-A Case Study of Sonitpur District of Assam"Volume-21 Issue7,Version-III July,2016Page 1 to 6

[7]. AlakaHujuri“"Women Empowerment through Entrepreneurship:A Case Study of Kamrup District of Assam"Volume-7 Issue12.December 2017Page no 404-424

[8]. Dr, Mu.Arumugam and DrC.Vijai“"Problems and Opportunities of Women Entrepreneurs in India."'Volume-2.Issue No-2January,2018Page 207 to 210
[9]. P.M SirumalarRajam,Dr K.U Soundaraja"Problems faced by women entrepreneurs:A Case study of Kanyakumari District."Volume-4,Issue-5,May,2016Page No 69-73

[10]. Unnikrishnan.P, S.Bhuvaneswari“A study on the issues and problems of women entrepreneurs in Kerela with special reference to Malappuram District."Volume-4 Issue-9 September-2016Page no 105-112

[11]. Websitesw.w.w.investopedia.com.Government of Assam portal 